\title{
MILITARISMO JURÍDICO, NORMALIZAÇÃO DISCIPLINAR E A JUSTIÇA CASTRENSE NO BRASIL
}

\author{
Fábio Gomes de França ${ }^{1}$ \\ Filipe Emanuel de Carvalho Guerra ${ }^{2}$
}

\begin{abstract}
RESUMO: Pretendemos neste artigo refletir sobre a relação que se estabelece entre o campo normativo-jurídico e a infrapenalidade disciplinar própria das casernas. Assim, através de uma pesquisa qualitativa de caráter bibliográfico, nosso argumento se sustenta por meio de uma discussão teórica sobre a criação e desenvolvimento da Justiça Militar no Brasil. Por fim, nossa intenção foi mostrar que as características das instituições disciplinares, assim como estudadas por Foucault, estão presentes no contexto do ordenamento penal castrense a partir de uma organização que se constituiu historicamente, ensejando a força da norma disciplinar em relação ao Direito normativo em nosso país, o que denominamos de um militarismo jurídico.
\end{abstract}

PALAVRAS-CHAVE: Militarismo jurídico. Normalização disciplinar. Justiça militar.

\section{LEGAL MILITARISM, DISCIPLINARY NORMALIZATION, AND THE MILITARY JUSTICE IN BRAZIL}

\footnotetext{
${ }^{1}$ Pós-Doutor em Direitos Humanos, doutor e mestre em Sociologia pela Universidade Federal da Paraíba. Professor de Criminologia e Sociologia do Centro de Educação da PMPB. E-mail: ffsociologia@gmail.com. Orcid: https://orcid.org/0000-0003-1917-840X.

${ }^{2}$ Especialista e bacharel em Segurança Pública pelo Centro de Educação da PMPB. Bacharel em Direito pela Unipê. E-mail: guerrafilipe@hotmail.com. Orcid: https://orcid.org/00000002-8707-4410.
} 


\begin{abstract}
This article discusses how was established the relationship between the legal field and the disciplinary infra-penality typical of barracks. Using a bibliographical qualitative research we put forth to argument through of a theoretical discussion on the creation and development of Military Justice in Brazil. In closing, we found that the characteristics of disciplinary institutions studied by Foucault are present in the Military Penal System in Brazil as can be seen through its historical organization. This influence enables that the disciplinary rules conditioning the military normative law in our country. We called this process of the legal militarism.
\end{abstract}

KEYWORDS: Legal militarism. Disciplinary normalization. Military justice.

\title{
MILITARISMO LEGAL, NORMALIZACIÓN DISCIPLINARIA Y LA JUSTICIA CASTRENSE EN BRASIL
}

RESUMEN: Pretendemos en este artículo reflexionar sobre la relación establecida entre el campo normativo-legal y la infrapenalidad disciplinaria típica de los cuarteles. Así, a través de una investigación cualitativa de carácter bibliográfico, nuestro argumento se sustenta mediante una discusión teórica sobre el desarrollo y la creación de la Justicia Militar en Brasil. Sin embargo, nuestra intención era mostrar que las características de las instituciones disciplinarias, así como estudiadas por Foucault, están presentes en el contexto de la orden penal de una organización que se constituyó históricamente, dando lugar a la fuerza de la norma disciplinaria en relación al derecho normativo en nuestro país, lo que llamamos militarismo legal.

PALABRAS CLAVE: Militarismo jurídico. Normalización disciplinaria. Justicia militar.

\section{INTRODUÇÃO}

No campo acadêmico, o Direito Penal Militar e o Direito Administrativo Militar ainda são áreas pouco exploradas, inclusive não existindo disciplinas que abordem as questões jurídicas das casernas nos cursos de Graduação em Direito no Brasil. Nesse sentido, claro que existe uma especificidade própria do direito castrense, o que, inclusive, tem permitido ultimamente escritos que se propõem a reconhecer um Direito Militar (SILVA et al., 2017), englobando, ao mesmo tempo, tanto a 
esfera penal quanto a administrativa militar. É a partir do reconhecimento dessa junção, em termos de uma concepção histórico-analítica nas ciências jurídicas, que nos propomos a refletir sobre a relação entre o que reconhecemos ser um militarismo jurídico e a normalização disciplinar (FOUCAULT, 1987) no Brasil.

Convencionamos chamar de militarismo jurídico neste artigo o processo pelo qual a perspectiva castrense, pautada nos ideais da hierarquia militar e da disciplina como técnica de organização dos indivíduos nos espaços de abrangência do mundo militar se desenvolve por condições morais em detrimento de concepções técnico-jurídicas. O militarismo jurídico enseja a força de presença, digamos assim, de elementos doutrinadores na construção de argumentos normativos fazendo com que, por exemplo, uma desobediência a superior hierárquico ganhe maior relevância jurídica do que uma lesão corporal praticada por um militar contra outro indivíduo.

Desse modo, a Justiça Militar no Brasil, desde o período colonial, foi influenciada pelo modelo jurídico advindo de Portugal, dadas as condições de o Brasil ter estado subordinado politicamente à Coroa portuguesa. Diante da introdução de mecanismos constitucionais de separação dos poderes do Estado ao longo do período monárquico e republicano, o poder central, em nosso país, desenvolveu formas de manter o controle do "braço armado do Estado" (Forças Armadas, Polícias e Bombeiros Militares), a nível federal e estadual. Assim, essas instituições caminharam atreladas a regulamentos morais e princípios constitucionais que as colocam em um campo apreciativo para além de uma perspectiva estritamente normativojurídica. De maneira que nosso objetivo principal foi mostrar como a criação e o desenvolvimento dessas instituições conforma a construção de uma noção de justiça presa a ditames morais disciplinadores a partir do modelo de existência pensado para essas instituições.

Levando-se em consideração a perspectiva foucaultiana sobre o desenvolvimento da sociedade disciplinar no Ocidente, o que diz respeito à adoção da disciplina como técnica política de organização dos indivíduos nas instituições de modo geral, como podemos melhor compreender a relação entre a norma disciplinar e o Direito no campo penal militar a partir 
da Justiça Militar nas Forças Armadas e nas Forças militares estaduais? Como se caracterizou no Brasil o que chamamos de militarismo jurídico?

Para tanto, utilizamos uma pesquisa qualitativa com caráter bibliográfico, pois, segundo Gil (2008), a pesquisa bibliográfica é desenvolvida a partir de material já existente, como livros, artigos científicos, monografias, dissertações e teses. Inicialmente, debruçamonos sobre a concepção de normalização disciplinar, assim como entendido por Foucault (1987), e como essa última invade o campo do Direito normativo para legitimar relações de poder que naturalizam as dissimetrias institucionais a partir de desigualdades hierárquicas (FONSECA, 2002). Por fim, nosso argumento se debruça sobre o desenvolvimento da Justiça castrense no Brasil para exatamente deixarmos claro como as instituições militares em nosso país demonstram, não de forma óbvia, como a força dos regulamentos aliada à cultura organizacional produziu instituições típicas do modelo disciplinar esboçado por Foucault $(1987,2003)$.

\section{ENTRE A LEI E A NORMA: COMPREENDENDO A RELAÇÃO ENTRE ASPECTOS JURÍDICOS E OS VALORES MORAL- DISCIPLINARES ${ }^{3}$}

A vida militar, alicerçada pela cultura castrense $e^{4}$ a qual impõe regras profissionais de convivência, é regida pela aplicabilidade de códigos

\footnotetext{
${ }^{3}$ Este tópico é uma versão adaptada das explicações encontradas em França (2014), as quais têm como suporte o ponto de vista foucaultiano acerca da relação entre a norma e o saber jurídico. Nesse caso, apresentamos neste artigo novas reflexões que partem inicialmente das proposições apresentadas em França (2014), mas que aqui ganham novos desdobramentos para abarcar a relação entre a norma disciplinar e o desenvolvimento histórico em nosso país das instâncias do Direito no campo militar e os saberes por elas produzidos, o que se traduz nos regimes de verdade que envolvem mecanismos normalizadores, assim como estudados por Foucault $(1987,2003)$.

${ }^{4}$ Cultura castrense, militarista ou, simplesmente cultura militar, pode ser entendida como o culto aos "princípios de hierarquia, disciplina, lealdade e honestidade de propósitos. Esses princípios alicerçam, nas respectivas instituições, as bases das suas particularidades, dos seus modus operandi peculiares, as quais passam a afetar o comportamento dos seus integrantes. Além disso, os valores institucionais são diariamente ritualizados, reatualizados, e as tradições e os seus heróis são lembrados em todos os momentos. Esse processo cognitivo acaba se incorporando em cada membro do grupo, criando um estereótipo que padroniza os seus componentes e, ao mesmo tempo, os diferencia" (MENEZES, 2015, p. 19-21).
}

Temáticas, Campinas, 28, (56): 107-136, ago./dez. 2020 
jurídicos e regulamentos administrativos específicos que orientam a conduta dos militares. Na Constituição de 1988 podemos encontrar em seu Art. 5, inciso LXI que "ninguém será preso senão em flagrante delito ou por ordem escrita e fundamentada de autoridade judiciária competente, salvo nos casos de transgressão militar ou crime propriamente militar, definidos em lei”. Neste caso, as transgressões militares ou disciplinares são matéria dos Regulamentos Disciplinares (RD), que incidem sobre o comportamento dos militares quando a disciplina militar passa a ser afetada. Já os crimes propriamente militares encontram sua tipificação no Código Penal Militar (CPM), o qual regula a ação ou omissão entendidas como ilícitos penais na seara militar, ou seja, "crimes militares próprios são aqueles cometidos contra a hierarquia e a disciplina militares como: motim, desrespeito a superior, recusa de obediência, publicação ou crítica indevida" (FRANÇA; DUARTE; ALVES, 2017, p. 84).

Em ambas as situações, tanto o RD quanto o CPM são os mesmos para as Forças Armadas e as Forças Militares Estaduais (Policiais e Bombeiros Militares). Isto se deve ao fato das Polícias e Bombeiros Militares em nosso país terem herdado o modelo de organização do Exército com maior destaque a partir do período ditatorial (1964-1985), o que foi ratificado pela Carta Magna de 1988.

Nesse contexto, a relação de proximidade entre as regras culturais da caserna e o modelo de organização das Forças Armadas e das Forças Estaduais nos direciona a melhor compreender como a concepção jurídicoadministrativa militar é sustentada por mecanismos não jurídicos de outra natureza que não os critérios legais que fundamentam o ordenamento positivo próprio ao Direito. Nossa visão baseia-se na afirmação de que o mundo militar é um exemplo par excellence de como a norma disciplinar (FONSECA, 2002; FOUCAULT, 1987, 2003, 2009; LOURENÇO, 2009; ROCHA, 2011) torna-se presente nos códigos jurídicos fortalecendo relações de poder. ${ }^{5}$ Estas relações de poder encontram na disciplina militar

\footnotetext{
${ }^{5}$ Outras explicações no campo dos estudos sobre os militares de modo geral baseiam-se no conceito de instituições totais de Erving Goffman (2007), no qual as instituições militares são vistas como tendo caráter de fechamento por servirem de local de trabalho, lazer e dormitório para os indivíduos. Nesse sentido, Castro (2004) rejeita essa propositura e afirma tratar-se de
} 
o modelo capaz de fazer as leis funcionarem sob o discurso da igualdade jurídica de condições aos indivíduos, ao mesmo tempo em que promove formas de submissão e desigualdade de caráter institucional. A norma infrapenal orienta-se no sentido de corrigir comportamentos cometidos por indivíduos nas instituições (incluam-se os militares) considerados "anormais" (FOUCAULT, 2001), ou melhor, contrários ao regime disciplinar.

Desenvolve-se, em torno da instituição judiciária e para lhe permitir assumir a função de controle dos indivíduos ao nível de sua periculosidade, uma gigantesca série de instituições que vão enquadrar os indivíduos ao longo de sua existência; instituições pedagógicas como a escola, psicológicas ou psiquiátricas como o hospital, o asilo, a polícia, etc. Toda essa rede de um poder que não é judiciário deve desempenhar uma das funções que a justiça se atribui neste momento: função não mais de punir as infrações dos indivíduos, mas de corrigir suas virtualidades (FOUCAULT, 2003, p. 86).

Corrigir as "virtualidades" dos indivíduos para que eles passem a disciplinar seus comportamentos de acordo com as regras institucionais abre a discussão para qual modelo de organização foi pensado e desenvolvido para as instituições (prisões, escolas, hospitais, quartéis, fábricas, asilos) na modernidade. Digamos que, em um "plano externo", a organização jurídica oriunda das Forças Armadas e estendida às PMs e BMs em nosso país seguiram os critérios de legalidade (princípio da isonomia) do modelo burguês de sociedade que visou estabelecer racionalmente o equilíbrio social por meio das instituições. É o que Foucault (1987) reconhece ser o

\footnotetext{
instituições totalizantes, porque no caso das casernas, diferentemente das prisões por exemplo, os indivíduos não são obrigados a viverem de forma forçada, são livres para se deslocarem. A visão de Castro aproxima-se da nossa, pois como instituição totalizante, as regras disciplinares acompanham os militares até mesmo nas folgas ao serviço, já que, como retrata um ditado muito conhecido da cultura militar: "Se é militar 24 horas por dia". Nesse caso, a força da norma moral-disciplinar presente implicitamente nos códigos jurídicos é a mesma que passa a acompanhar os militares em todos os aspectos de sua vida.
} 
sonho iluminista de sociedade baseado nos princípios jurídicos oriundos do contrato social. No entanto, por uma perspectiva ideológica, sabemos que "Lei e Código instalaram-se, veladamente, como alicerces garantidores da imutabilidade social, consolidando uma sociedade de privilégios e de desigualdades" (LOURENÇO, 2009, p. 76). Esta explicação sugere que o modelo positivista dos ordenamentos jurídicos ocidentais, dentre eles o brasileiro, é utilizado para manter as desigualdades comuns à esfera econômica, se visto por uma perspectiva ideológica. De modo inverso, em um "plano interno" de análise, tem-se que as relações de poder antecedem as concepções ideológicas que sustentam desigualdades econômicas, especialmente entre classes (FOUCAULT, 2003). Por exemplo, operários precisam ser antes adestrados e disciplinados para depois serem explorados no mundo do trabalho, assim como os militares precisam ser antes também condicionados disciplinarmente para depois arriscarem suas vidas para cumprir suas missões de forma resignada sem contrariar ordens recebidas.

É neste sentido que surge a articulação entre norma e Direito, de modo que a primeira fortalece um poder cunhado de disciplinar (FOUCAULT, 1987, 2003) e o qual funciona em rede de forma microfísica, ou seja, todos em sociedade podem exercer poder, ao mesmo tempo em que a lógica do poder disciplinar também suscita resistências, por isso ser vislumbrada como relação de poder. Por exemplo, a relação entre pais e filhos, professores e alunos, gerentes e operários fabris, comandantes e subordinados na esfera militar. As relações que envolvem o poder disciplinar passam por todos os indivíduos, de maneira que o poder não pode ser visto como uma coisa a ser apropriada por alguém, nem quanto menos se localizar em pontos fixos, tornando-se transmissível enquanto uma relação para caracterizar o que vem a ser a distinção entre indivíduos "normais" e "anormais".

O ponto chave da questão, segundo a visão foucaultiana, é que as relações de poder funcionam nas instituições de forma produtiva tendo a disciplina como técnica, ou seja, no caso dos militares, quanto mais são treinados para serem obedientes, mais eles reconhecem essa dominação sobre eles de forma positiva, por estarem sendo preparados para a guerra, mesmo que suas vidas possam ser colocadas em risco. Quanto mais um 
soldado se resigna às regras da caserna tornando-se obediente aos seus superiores para realizar tudo aquilo que lhe ordenam, mais se torna um corpo "útil e dócil" (FOUCAULT, 1987), o que na concepção do soldado passa a ser visto como algo bom, visto que ele está sendo reconhecido pelo que faz e produz de acordo com a apreciação daqueles que lhe prescrevem as ordens para serem cumpridas.

O militar passa a ser um corpo produtivo e cada vez mais dominado, sendo diminuída sua compreensão política sobre o lugar que ocupa na hierarquia institucional. Ele sente-se satisfeito pelo fato de obedecer a alguém cumprindo as tarefas que lhe são impostas de forma eficiente. Por isso, o poder disciplinar funciona como algo positivo e não negativo. Ele não faz uso da coerção, mas adestra e condiciona os corpos dos indivíduos através da repetição constante de atividades, fazendo-os internalizarem eficazmente o automatismo dos hábitos cotidianos, pois como já afirmou Foucault (1987, p. 117), "o soldado tornou-se algo que se fabrica”.

Essa "microfísica do poder" promove uma descentralização do espaço jurídico que, por esse viés acaba por estender-se igualmente pelas instituições disciplinares, ou seja, "nelas existe uma microfísica jurídica, uma dilatação do Direito, do direito de admoestar, senão sempre o corpo, pelo menos o espírito" (ROCHA, 2011, p. 46-47). A norma antecede a normatividade jurídica exercendo controle social, visto que, nas diversas instituições disciplinares, assim como as Forças Armadas, Polícias Militares e Bombeiros Militares, funcionam regimes punitivos que têm a função de dirimir os pretensos desvios de conduta e afastar aqueles que não se enquadram no que prescrevem essas instituições.

A sanção recebida pelo sujeito seria sua "adequação" ao conjunto de regras e comportamentos esperados e previstos, valorizados dentro dessa necessidade de homogeneização. Neste sentido fala-se em positividade da norma, a qual não produziria um sofrimento, uma expiação diretamente, mas se voltaria às condutas, aos comportamentos a fim de conformá-los ao padrão desejável pela coletividade (LOURENÇO, 2009, p. 22). 
Baseando-se no exposto, podemos afirmar que "as práticas e os saberes jurídicos, ao menos em parte, funcionam como vetores e agentes da normalização efetuada sobre a vida e seus processos" (FONSECA, 2002, p. 234). Na verdade, as respostas jurídicas no mundo castrense tornam-se eivadas por condições morais que sustentam a cultura militarista. Essa condição, antes de estabelecer uma divisão entre os princípios e mecanismos jurídicos e as culturas institucionais, ao contrário, realiza uma aproximação, ou seja, a "lei combina com o poder em várias localizações a partir de formas que expandem os padrões de controle social, conhecimento e a documentação sobre os indivíduos para fins institucionalmente utilitários (TURKEL, 1990, p. 170, tradução nossa). ${ }^{6}$ Se existe uma política ao nível de visibilidade das instituições que objetivam à sujeição do corpo e das subjetividades de forma mútua, destacadamente de forma moral por meio de acepções jurídicas, então, "ali se encontra igualmente um direito de julgar e punir - e qualquer ação que provoque ruptura na ordem é um motivo para se julgar e punir - não um direito educacional per se, mas sob os auspícios da legalidade” (ROCHA, 2011, p. 47).

Ao cunhar de "sanção normalizadora" a infrapenalidade jurídicoinstitucional que atua como força moral disfarçada de lei, Foucault (1987) quer nos dizer que a norma opera regulando a conduta dos indivíduos nas instituições. Em síntese, a normalização disciplinar baseia-se no fato de a disciplina vincular-se a uma técnica de ordenação dos corpos, atitudes e pensamentos, de forma que todas as ações e omissões que quebrem as regras disciplinares (atrasos, falta de cuidado com o asseio pessoal, falta de atenção às posturas e atos corporais, falta de zelo com os ambientes e materiais que se utiliza, falta de respeito com os superiores) devem ser penalizadas. Se ao Direito cabe implementar um discurso que se alicerça pela igualdade jurídica, por outro lado, à disciplina resta o papel de ocultar a desigualdade por meio desse mesmo discurso. Vejamos como o problema da norma (moral e hierarquizadora) relaciona-se com a lei normativa (com pretensões isonômicas e garantidoras de direitos) a partir do olhar sobre a construção histórica da justiça no seio da esfera militar no Brasil. Tal

6 "Law combines with power in various locations in ways that expands patterns of social control, knowledge, and the documentation of individuals for institutionally useful ends". 
questão nos clarifica como a norma jurídica e a norma disciplinar são coisas distintas, já que, a última se utiliza da primeira para impor sua força.

\section{A CONSTRUÇÃO DA JUSTIÇA CASTRENSE NO BRASIL}

O Direito Penal é um instrumento consolidado no tempo, utilizado como mecanismo de controle, manutenção da paz e ordem pelas organizações humanas. O Direto Penal e a Justiça Militar desenvolveram-se conjuntamente no Ocidente com o surgimento das primeiras organizações militares. Na Roma Antiga encontram-se as primeiras codificações militares que eram aplicadas às legiões, o que possibilitou exatamente o surgimento de um direito militar, considerado como instituição jurídica (LOUREIRO NETO, 1993). Elaborado por determinação do imperador Justiniano, a coletânea Digesto, DE RE MILITARE, promulgada em 15 de dezembro de 533, apresenta disposições que diferem a jurisdição civil da militar, ou seja, "os delitos ou crimes dos soldados, ou lhes são próprios, ou comuns a eles e aos demais cidadãos: donde o processo é próprio ou comum. Propriamente militar é o delito que alguém comete como soldado" (CORREA, 1991, p. 45).

O direito romano atribui competência à Justiça Militar baseada no critério ratione materiae, ou em razão do fato, ou da natureza do delito, o que serviu de base aos diversos ordenamentos jurídicos atuais. Quanto às punições, foi elaborado um sistema com 03 (três) penas: as capitais, que privavam o infrator de sua vida natural, ou lhe retirava o Status Civita, tornando-o escravo; as penas corporais ou aflitivas constituídas por castigo, multa, trabalhos forçados, transferência de milícia, degradação, baixa infamante e, por último, as penas disciplinares ou morais, constituídas por sanções aplicadas muito mais pelos costumes do que por prescrições em norma específica. Nessas últimas, a natureza da pena imposta era deliberada pelo próprio grupo em face de condutas cotidianas do serviço militar romano como: "invernar fora dos lugares fortificados, em campo aberto; servir-se em pé dos alimentos; apresentar-se descalço com a túnica e sem cinturão no lugar do campo chamado; abrir as veias e extrair o sangue diante das legiões" (BANDEIRA, 1919, p. 187). Nesse sentido, 
parece-nos que, pensando em termos genealógicos, estamos diante de um exemplo de como a norma disciplinar mostrava-se de forma embrionária para depois alcançar toda uma sociedade disciplinar séculos depois que superada, em certo sentido, a racionalidade punitiva do regime suplicial do século XVIII (FOUCAULT, 1987, 2009).

Desse modo, a monarquia portuguesa utilizou o modelo romano como paradigma para sua estrutura jurídica. Seus primeiros ordenamentos jurídicos ficaram conhecidos pelas denominações dos monarcas que os instituíram. Em 1446, sob o reinado de Dom Afonso, foi publicado o primeiro código jurídico daquele reino, conhecido como Ordenações Afonsinas. Durante o reinado de Dom Manuel (1495-1521), as Ordenações Afonsinas foram substituídas pelas Ordenações Manuelinas, as quais vigeram até 1580. Quando Felipe II, rei da Espanha, assume o trono de Portugal, instauram-se as Ordenações Filipinas (1603) como instrumento jurídico vigente sobre Portugal e seus territórios conquistados. Em 1763, as ordenações Filipinas deixam de tratar temas referentes ao Direito Penal e Disciplinar Militares, sendo substituídas pelo Regulamento do Conde de Lippe. $^{7}$ A nova legislação ainda tratou de temas como ensino, recrutamento, formação em campo de batalha e, principalmente, a disciplina. Os Artigos de Guerra criados pelo Conde de Lippe proporcionaram que o regulamento fosse associado primeiramente ao severo código disciplinar do que ao conjunto da obra. Tal regulamento foi primeiramente aplicado à Arma de infantaria e posteriormente passou a ser aplicado às demais armas do reino (COSTA, 2010).

A principal modificação trazida pela nova legislação na Justiça Militar foi a alteração quanto à competência dos antigos Conselhos de Guerra. Tais Conselhos tinham sido criados no reinado de D. João, duque de Bragança, em 11 de dezembro de 1640, e passou a atuar durante o período da Guerra de Restauração (1640-1668) pelo trono português que estava sob o jugo espanhol (COSTA, 2009). Com o Conde de Lippe,

\footnotetext{
${ }^{7}$ Sebastião José de Carvalho e Melo, o Marquês de Pombal, pediu à Inglaterra um militar que pudesse instruir as tropas portuguesas, sendo indicado Wilhelm Lippe, Conde de Schaumbourg, oficial alemão que teria prestado serviços à Marinha Inglesa. Assim foi convidado pelo Rei D. José I, de Portugal, para reestruturar o exército português, no Século XVIII.
} 
foram criados novos Conselhos de Guerra que passaram a atuar como tribunais para deliberações de primeira instância atrelados a Regimentos Militares, enquanto aqueles criados em 1640 passaram, sob a regência de D.Maria I, a tribunais de justiça militar de segunda instância denominandose Conselhos de Justiça (SOUZA, 2015). O novo regulamento criado pelo Conde de Lippe rompeu uma prática antiga, que dava aos magistrados o direito de livre interpretação das leis, eliminando a hegemonia dos juristas sobre as matérias militares do governo, ou melhor, "todo crime devia ser provado, não estando os Artigos de Guerra sujeitos ao arbítrio e interpretações dos juízes" (SOUZA, 2018, p. 64).

Além disso, o regulamento de Lippe ficou conhecido pela imposição de uma disciplina rígida e pelo rigor das penas. Diante de uma insatisfação com a nova legislação, considerada draconiana, a corte portuguesa institui em 21 de março de 1802 uma comissão encarregada por elaborar um projeto de Código Penal Militar (BANDEIRA, 1919; SOUZA, 2018), o que indica um ponto de intersecção no desenvolvimento do modelo disciplinar e o tipo de racionalidade que lhe é própria com a esfera jurídica (FONSECA, 2002; FOUCAULT, 2003; ROCHA, 2011).

Souza (2018, p. 64) deixa ainda mais clara essa proposição ao citar Hespanha (1993) afirmando-nos que "essa gramática produziu uma inversão no exercício da prática penal, levando à substituição da justiça pela disciplina como ideia dessa ação". Parece-nos que é nesse momento que houve certa legitimação do processo de consolidação do Direito Penal Militar que se estendeu ao Brasil e das práticas discursivas (FONSECA, 2002; FOUCAULT, 1987) que o reitera, através de Códigos e instituições. Mesmo que esse código pensado para ser validado no início do século XIX não tenha sido sancionado, pelo menos no campo das ideias e dos escritos que surgiram dos debates da comissão de elaboração, vê-se o encontro de normativas jurídicas (de acordo com o modelo iluminista) e da norma disciplinar como medida corretiva aos militares, o que resulta nas primeiras configurações de um militarismo jurídico.

Em 1808, com a chegada da família real ao Brasil, alterou-se o status na cidade do Rio de Janeiro que passou a ser a capital do império e nela foram instalados diversos órgãos públicos até então existentes apenas em 
Portugal, a exemplo do Conselho de Estado, das Mesas do Desembargo do Paço e da Consciência e Ordens e do Conselho da Fazenda. Quanto ao sistema judicial foi instituído pelo Alvará de 01 de abril de 1808 o Conselho Supremo Militar e de Justiça, enquanto o órgão julgador presente na colônia recebeu a elevação de instância passando a ser denominado, pelo Alvará de 10 de maio de 1808, Casa de Suplicação do Brasil (CHAVES, 2017).

Em 1822, com a proclamação da independência do Brasil, ocorre uma efervescência para a instituição de um arcabouço jurídico próprio e que atendesse às particularidades do novo país. Em 1824 é outorgada a Carta Constitucional imperial, que inovou em garantias de direitos fundamentais: aboliu a tortura e os açoites, entretanto, tais castigos continuaram a ser aplicados em negros fugidos do cativeiro e a soldados e marinheiros enquadrados em transgressões disciplinares. ${ }^{8}$ Com a primeira Constituição, foi instituída a separação formal dos poderes do Estado. ${ }^{9}$ Entretanto, os tribunais militares não passaram a integrar a estrutura do Poder Judicial. ${ }^{10}$ A Justiça Militar no período imperial foi caracterizada por uma multiplicidade de órgãos julgadores, da plena submissão aos comandos militares e de sutilezas que diferenciavam crimes militares dos comuns (ROMEIRO, 1962).

Em 1830 é promulgado o Código Criminal do Império, lei de 16 de dezembro de 1830 , que por força do art. $308^{11}$ não seria aplicado aos crimes puramente militares. $\mathrm{O}$ ministro da guerra, em relatório encaminhado à Assembleia Geral em 1832, demonstra preocupação com legislação aplicada aos militares (BRASIL, 1830, p. 7, grifo nosso):

\footnotetext{
${ }^{8}$ A chibatada como castigo disciplinar foi abolida pelo aviso do Ministério da Guerra em 16 de julho de 1831, por ser aviltante para o Exército, e por não ter fundamento em lei. Entretanto, continuou a ser aplicada até depois da proclamação da República.

${ }^{9}$ Art. 10: Os Poderes políticos reconhecidos pela Constituição do Império do Brasil são quatro: o Poder Legislativo, o Poder Moderador, o Poder Executivo e o Poder Judicial.

${ }^{10}$ Art. 150. Uma ordenança especial regulará a organização do Exército do Brasil, suas promoções, soldos e disciplina, assim como da força naval.

${ }^{11}$ Art. 308. Este Código não compreende: $2^{\circ}$ Os crimes puramente militares, os quais serão punidos na forma das leis respectivas.
} 
O Militar Brasileiro deve ser respeitado como benemérito defensor da sua Pátria: se os princípios disciplinares exigem dele uma obediência regulada; se a segurança do Império reclama o sacrifício temporário de uma porção da sua liberdade legal, nem por isso o Soldado deve ser considerado como instrumento das paixões desregradas dos seus respectivos Chefes: as condições e os limites à obediência devem ser bem definidos, e o Governo confia em o Corpo Legislativo; que se dignará prestar as suas providentes atenções a favor do Exército do Império, $e$ que bem depressa lançará por terra a Legislação Gótica a que ainda no tempo presente se acham agrilhoadas as Tropas de uma Nação civilizada, e Constitucional.

Assim, com a lei de 29 de novembro de 1832, Código de Processo Criminal de Primeira Instância ${ }^{12}$, surge a definição legal brasileira dos crimes puramente militares na clássica divisão: ratione personae e ratione materiae, sendo-lhes ainda aplicado o Código de Lippe. Nesse sentido, o Poder Legislativo inicia uma produção legislativa para tratar determinados temas de direito militar: o Decreto $\mathrm{n}^{\mathrm{o}}$ 01, de 26 de maio de 1835, que dispõe sobre deserção dos oficiais da Armada e do Exército; a lei 201, de 03 de dezembro de 1841, produz uma reforma no Código de Processo Criminal reforçando em ratione materiae: militares serão julgados pelas leis e Tribunais Militares. Esses fatos demonstram que estamos diante de um processo que levou anos para alcançar certa maturidade, pois estamos tratando do amadurecimento de um campo do Direito específico

\footnotetext{
${ }^{12}$ Art. $8^{\circ}$ Ficam extintas as Ouvidorias de Comarca, Juízes de Fora, e Ordinários, e a Jurisdição Criminal de qualquer outra Autoridade, exceto o Senado, Supremo Tribunal de Justiça, Relações, Juízos Militares, que continuam a conhecer de crimes puramente militares, e Juízos Eclesiásticas em matérias puramente espirituais.

Art. 171. A acusação dos empregados públicos não privilegiados será feita perante o Júri competente. Excetuam-se: $1^{\circ}$ Os militares que por crimes do emprego militar serão acusados no Juízo do seu foro.

Art. 324. Continuam a ter vigor os processos marcados na Lei da responsabilidade dos Ministros de Estado e Conselheiros de Estado, e na do Supremo Tribunal de Justiça, assim como as do Foro Militar em causas meramente militares, e as do Foro Eclesiástico em causas puramente espirituais.
} 
no qual dialogavam a busca de regras normativas codificadas, punições disciplinares como forma de controle das tropas (FOUCAULT, 1987) e a existência também de castigos físicos às Praças para mantê-las no lugar de subordinação que lhes cabia na hierarquia militar.

O Poder Legislativo brasileiro buscou organizar a legislação e Justiça Militares em projetos conduzidos pelos legisladores Nabuco Araújo, em 1850, Magalhães Castro, em 1860, entretanto não consegue aprovar nenhum deles. Em 1862 o Ministro e Secretário de Estado dos Negócios da Guerra, o então Marquês de Caxias $^{13}$ demonstra uma grande preocupação de como eram aplicadas as penas dos Crimes militares e as Penas Disciplinares, pois as formas de execução eram inconvenientes com a disciplina militar. Assim, propôs um projeto para estabelecer o Regulamento Correcional das Transgressões Disciplinares a fim de substituir o Regulamento Disciplinar do Conde de Lippe, expondo para tanto (BRASIL, 1862, p. 4): "regularizar o arbitrio na aplicação dos castigos correcionais adotadas no exército, declarar quais as autoridades que podem impô-los, a que classe de subordinados, e por que meios; e bem assim marcar os limites desses castigos". Entretanto, tal projeto não chegou a entrar em vigência, pois o Conselho Supremo Militar e de Justiça consultado sobre o projeto não se manifestou. No ano seguinte o substituto da pasta independente de qualquer deliberação do Tribunal decidiu não por em execução (BRASIL, 1863, p. 16): "Não tendo, porém, chegado a pô-lo em pratica, também não me resolvi a fazer, independente de qualquer deliberação vossa, em consequência de ter sido o referido projeto submetido ao vosso esclarecido juíro".

Com o fim da monarquia e a promulgação em 24 de fevereiro de 1891 da primeira Constituição da República, algumas normas são inseridas no texto constitucional: a obrigatoriedade do serviço militar, o fim do recrutamento forçado e a reorganização geral do Exército. A Justiça Militar sofre alterações por força do Decreto Legislativo no 149 , de 18 de julho de 1893 e o Conselho Supremo Militar e de Justiça transformou-se em Supremo Tribunal Militar, continuando a exercer as mesmas atribuições. Os atores políticos conseguem a aprovação do Código Penal da Armada,

${ }^{13}$ Luís Alves de Lima e Silva, o Duque de Caxias é o patrono do exército brasileiro, conforme Decreto Federal no 51.429, de 13 de março de 1962. 
Decreto $\mathrm{n}^{\mathrm{o}}$ 18, de 7 de março de 1891, estendido para o Exército pela Lei n ${ }^{\circ}$ 612, de 29 de setembro de 1899 e posteriormente aplicado à Força Aérea, pelo Decreto-Lei no 2.961, de 20 de janeiro de 1941. Em 24 de janeiro de 1944 foi aprovado o primeiro Código Penal Militar comum às Forças Armadas, Decreto-Lei n ${ }^{\circ}$ 6.227, sendo revogado pelo Decreto-Lei no 1.001, datado de 21 de outubro de 1969, vigente até hoje.

No processo de construção do poder central da União Federal é Promulgada a Constituição de 16 de julho de 1934. Como mecanismo de afirmação do Poder da esfera militar tem-se uma alteração na composição do Poder Judiciário. Nos órgãos colegiados a maioria das indicações passava pelo crivo do chefe do Poder Executivo Federal, que detinha amplo poder discricionário para escolher os juízes e assim indiretamente influenciar na composição da Justiça Militar Federal. Ressalte-se que o foro militar ${ }^{14}$ passou a julgar civis na condição de assemelhado, ou seja, pessoas que não pertencendo à classe militar exerciam funções de caráter civil ou militar em lugares e estabelecimentos de natureza e jurisdição militar e sujeitos por isso a preceitos de subordinação e disciplina previstos nas leis e regulamentos disciplinares, ou seja, uma boa prova de como passou a funcionar no Brasil aspectos da sociedade disciplinar estudada por Foucault (1987) mostrando-nos como a perspectiva disciplinar antecede a busca objetiva do Direito visando fatos jurídicos (LOURENÇO, 2009).

A União, buscando consolidar o poder sobre as Polícias Militares ${ }^{15}$ inclui no texto constitucional dispositivo que compulsoriamente as tornam forças reservas do Exército ${ }^{16}$ e quando mobilizadas ou a serviço

${ }^{14}$ Art. 84 - Os militares e as pessoas que lhes são assemelhadas terão foro especial nos delitos
militares. Este foro poderá ser estendido aos civis, nos casos expressos em lei, para a repressão
de crimes contra a segurança externa do país, ou contra as instituições militares. Nesse sentido,
entenda-se foro militar como direitos ou privilégios concedidos pela Justiça Militar àqueles que
lhe são pertinentes.
15 O artigo $7^{\circ}$ do Decreto n ${ }^{\circ} 12.790 / 1918$ já possibilitava que: "A Brigada Policial e o Corpo de
Bombeiros do Distrito Federal, bem como as forças policiais militarizadas dos Estados nos termos do art. $7^{\circ}$ da
lei n. 3.216 , de 3 de janeiro do 1917 constituirão as forças auxiliares do Exercito ativo".
${ }^{16}$ A lei no 3.216 , de 3 de janeiro de 1917 , já fazia previsão da condição de forças policiais
como auxiliares do Exercito Nacional: art. $7^{\circ}$ Na forma do art. 10 , $\int 3^{\circ}$, do decreto n. 11.497 ,
de 23 de fevereiro de 1915 , a Brigada Policial do Distrito Federal, o Corpo de Bombeiros desta Capital,
as policias militarizadas dos Estados, cujos governadores estiverem de acordo, passarão a constituir 
da União gozarão das mesmas vantagens atribuídas à força terrestre. Sendo as Polícias Militares ${ }^{17}$ órgãos dos Estados e diante da autonomia conferida pelo pacto federativo, a União não teria como intervir em sua organização. A solução encontrada foi a aprovação da Lei Federal no 192, de 17 de janeiro de 1936, que reorganizou a estrutura das Polícias Militares, impondo-lhes uma série de limitações quanto ao efetivo, material bélico, uniformes e aplicação dos regulamentos militares vigentes no Exército. Ainda como forma de ampliar o controle sobre os integrantes das forças policiais locais, essa legislação autorizou a organização da Justiça Militar nos Estados, submetendo os oficiais, aspirantes-a-oficial, sargentos praças das Polícias Militares às normas estabelecidas no Código Penal Militar. Nesse caso, amplia-se o alcance jurídico-disciplinar às Polícias Militares como forças estaduais auxiliares ao Exército Regular, o que nos leva, em certo sentido, à reflexão de que, além do conteúdo político devido à participação da então Força Pública paulista na revolução de 1932, reforça-se uma concepção moral própria do sistema disciplinar em fazer os militares estaduais sofrerem certa ortopedia correcional por meio da disciplina (FOUCAULT, 1987, 2003).

Passado o período varguista, e convocada uma Assembleia Nacional Constituinte em 18 de setembro de 1946, o Brasil passa a ser regido por uma nova Constituição. Nela, a Justiça Militar continua a integrar o Poder Judiciário, sendo incorporada ao texto constitucional a estrutura da Justiça Militar Estadual. Quantos aos civis, a extensão do foro castrense só aconteceria na ocorrência de crime militar ou de crimes contra as instituições militares ou contra a segurança externa do país. A redação do

forças auxiliares do Exercito Nacional, ficando isentos os oficiais e praças das ditas corporações das exigências do sorteio militar. Grifo nosso.

Art. $8^{\circ}$ Para os efeitos do artigo anterior a Brigada Policial e o Corpo de Bombeiros do Distrito Federal, bem como as policias estaduais, que tiverem organização eficiente, a juíro do Estado-Maior do Exercito, serão considerados forças permanentemente organizadas, podendo ser incorporadas ao Exercito Nacional em caso de mobilização deste e por ocasião das grandes manobras anuais.

${ }^{17}$ Devemos deixar claro que, desde a criação das primeiras Guardas Municipais Permanentes nas províncias ainda no período regencial, essas instituições receberam variadas denominações, até, definitivamente, não de maneira uniforme, mas em datas diferenciadas no período varguista em nosso país nos diversos estados, passarem a chamarem-se Polícias Militares. 
art. 183 considera as Polícias Militares como forças auxiliares, reservas do Exército. Isso significa dizer que a lógica disciplinar permaneceu constante na passagem de um período autoritário para um mais democrático traçando as diretrizes para uma concepção de justiça pautada em critérios morais das casernas. Nesse sentido, podemos levantar a explicação do protecionismo militar em não admitir o julgamento pleno de questões militares apenas por juízes civis por meio do argumento de que só os próprios militares conhecem as regras da cultura militar, o que ratifica nosso argumento de uma justiça regida pelo condão da disciplina e de critérios morais nãoobjetivos. Adiante, explicamos melhor esse princípio que se dá por meio do escabinato.

Assim, a competência da Justiça Militar foi ampliada pela Lei Federal 4.162, de 04 de dezembro de 1962. A redação do artigo 88, letra 1, do Código de Justiça Militar de 1938 foi alterada para julgar também os crimes cometidos em serviços de natureza policial. Até então, oficiais e praças das polícias estaduais só podiam ser submetidos ao código militar quando incorporados às forças federais, entretanto, em 1963, tal preceito legal torna-se inaplicável frente à Súmula 297 do Supremo Tribunal Federal (STF): "Oficiais e praças das milícias dos Estados no exercício de função policial civil não são considerados militares para efeitos penais, sendo competente a Justiça Comum para julgar os crimes cometidos por ou contra eles".

Instaurado o Golpe Militar de 1964, outorgada a Constituição do Brasil de 1967, a União manteve a competência privativa de legislar sobre organização, efetivos, instrução, justiça e garantias das polícias militares e condições gerais de sua convocação, inclusive mobilização (art. $5^{\circ}$, inciso XVII, alínea v). Inova o texto constitucional em lhes atribuir finalidade, dispondo-lhes que são instituídas para os fins de manutenção da ordem e segurança interna nos Estados, nos Territórios e no Distrito Federal. São, novamente, consideradas forças auxiliares, reserva do Exército (art. 13, $\int 4^{\circ}$.). Entretanto, o sistema jurídico as mantém subjugadas pela cultura da caserna, sujeitando-as igualmente a: instrução, regulamentos ${ }^{18}$ e justiça militar (ZAVERUCHA, 2010).

${ }^{18}$ O Regulamento Disciplinar do Exército tinha sido aprovado pelo Decreto n ${ }^{\circ} 8.835$, de 23 de fevereiro de 1942. 
Buscando aumentar o controle sobre as Polícias Militares e os Corpos de Bombeiros Militares a União edita o Decreto-lei n. ${ }^{\circ} 317$, de março $1967^{19}$, criando a Inspetoria Geral das Polícias Militares - IGPM, órgão do Ministério da Guerra encarregado por estudos, coleta e registro de dados, bem como do assessoramento referente ao controle e coordenação dos militares estaduais. A partir de então as Corporações estaduais tiveram seu controle reforçado por Regulamento Disciplinar redigido à semelhança do Regulamento Disciplinar do Exército.

Em 1977, com a aprovação da Emenda Constitucional n ${ }^{\circ} 07^{20}$, torna-se superada a Súmula 297 do STF. A corte deliberou no julgamento do Habeas Corpus no 956.049-SP, de 13 de junho de 1978, Relator Ministro Rodrigues Alckmin, que o crime cometido por policiais militares no policiamento ostensivo de trânsito seria da competência da Justiça Militar, propondo, ao final, a reformulação da Súmula 297. Assim, continuou a competência da Justiça Comum para alcançar os civis que cometessem crimes contra policiais militares, mas os crimes destes, em ações policiais, passavam para a esfera da Justiça Militar Estadual. O que se vê é que, no período ditatorial, a ideia da norma disciplinar alcançou ainda mais efetividade ao ser reforçado o controle por parte do Exército (instituição disciplinar por excelência) às forças militares estaduais. Se até 1977 era possível os PMs, por exemplo, serem julgados por civis no cometimento de alguns crimes, isso quer dizer que o discurso protecionista do julgamento de militares por outros militares devido ao conhecimento da cultura castrense não se justifica, a não ser pela ideia de revigorar a norma disciplinar que se camufla pelo discurso jurídico dos códigos e regulamentos (FOUCAULT, 1987).

Convocada a Assembleia Nacional Constituinte em 1987, verificase nos anais da constituinte que se debateu na Subcomissão de Defesa do

\footnotetext{
${ }^{19}$ O Decreto-lei n. ${ }^{\circ} 317$ de 13/03/1967 foi revogado pelo Decreto-Lei no 667, de 2 de julho de 1969, até então vigente. A IGPM deixa a estrutura do Ministério da Guerra e passa para o Estado Maior do Exército.

${ }^{20}$ d) Justiça Militar estadual, constituída em primeira instância pelos Conselhos de Justiça e, em segunda, pelo próprio Tribunal de Justiça, com competência para processar e julgar, nos crimes militares definidos em lei, os integrantes das polícias militares.
} 
Estado, da Sociedade e de sua Segurança, sobre a manutenção das forças policiais e Corpos de Bombeiros como organizações militares e sujeitos à Justiça Militar. O relatório final opta pela manutenção da militarização do serviço policial e o sistema judiciário militar nos moldes do "período de chumbo". Uma parte da Constituição permaneceu praticamente idêntica à Constituição de 1967 e à sua emenda de 1969, quanto às cláusulas relacionadas às polícias militares estaduais, às Forças Armadas (ZAVERUCHA, 1999). A Constituição de 1967 foi outorgada após um golpe militar. Some-se que, até a convocação existiu todo um contexto histórico de malversação dos serviços da Polícia Militar pelas Forças Armadas.

Assim, a Carta Cidadã promulgada, ao invés de clarificar e distinguir o serviço de Segurança Pública interno do país como uma função civil, ao contrário, no inédito capítulo da Segurança Pública continuou-se a adotar um modelo militarizado, impondo-lhe a hierarquia e disciplina como um preceito basilar e, mantendo as forças militares estaduais subjugadas às Forças Armadas (ZAVERUCHA, 2005).

A Constituição Federal de 1988 manteve a instituição da Justiça Militar na estrutura organizacional do Poder Judiciário, bem como, a composição e competência dos juízos julgadores. Na justiça castrense, a formação dos órgãos julgadores será sempre colegiada e a maioria dos membros sempre será oriunda das organizações militares. Na Composição do Conselho Nacional de Justiça, órgão administrativo do Poder Judiciário responsável pelo controle administrativo, financeiro e disciplinar da magistratura, não existe nenhum representante da Justiça Militar.

Segundo a Carta Magna de 1988, a composição no âmbito Federal da Justiça castrense de primeira instância é constituída pelos juízes auditores. Investidos na magistratura por meio de concurso público específico àquele ramo do direito, de igual maneira o Ministério Público Militar é um ramo autônomo do Parquet da União, cujos cargos são investidos por meio de concurso público. Existe ainda o órgão maior de última instância dessa justiça especializada, o Superior Tribunal Militar, composto por oficiais-generais da Marinha, do Exército, da Aeronáutica, todos da ativa e do posto mais elevado da carreira, e cinco dentre civis. Quanto à sua 
competência foi-lhe atribuída para processar e julgar os crimes militares ${ }^{21}$ definidos em lei, praticados tanto por civis quanto por militares das Forças Armadas.

A Justiça Militar Estadual não encontra simetria no modelo da União, primeiramente pela faculdade atribuída pela própria Carta Magna de 1988 de que os Estados possam implantar um Tribunal de Justiça Militar, cujo efetivo seja superior a vinte mil integrantes, e assim possa existir uma carreira dos juízes de direito do juízo militar ou funcione em primeiro grau, pelos juízes de direito e pelos Conselhos de Justiça e, em segundo grau, pelo próprio Tribunal de Justiça. Em todos os casos sua competência restringe-se para processar e julgar, nos crimes militares definidos em lei, os militares dos Estados e as ações judiciais contra atos disciplinares militares. ${ }^{22}$ Não existe um Ministério Público Militar estadual. Os membros do Parquet atuantes nessa Justiça especializada são designados pelo chefe do Ministério Público.

Em âmbito estadual, os recursos impetrados das decisões judiciais dos juízos de primeira instância seguem para um dos 27 tribunais de Justiça, ou para um dos 03 tribunais de Justiça Militar (São Paulo, Minas Gerais, Rio Grande do Sul). A partir da segunda instância não existe um órgão específico para processar e julgar os recursos judiciais dos TJ's e TJM's, o que favoreceria a uniformização da Jurisprudência. Pelo contrário, verifica-se a ocorrência de divergências interpretativas e jurisdicionais dos Tribunais de Justiça como, por exemplo, aplicabilidade à Justiça Militar do rito especial previsto na Lei no 9.099/95, matéria já sumulada perante a Justiça Militar da União. ${ }^{23}$ Por outro lado, se no caso dos militares estaduais, nos estados que não possuem Tribunais Militares próprios, a $2^{\mathrm{a}}$ instância funciona em regime civil sem nenhuma participação militar no julgamento de recur-

${ }^{21}$ Cabe à Justiça Federal a competência para processar e julgar ações judiciais contra atos disciplinares militares das Forças Armadas.

${ }^{22}$ A Emenda Constitucional n 45, de 08 de dezembro de 2004, modificou a estrutura do Poder Judiciário e ampliou a competência da justiça militar estadual para julgar as ações judiciais contra os atos disciplinares militares.

${ }^{23}$ STM. Súmula No 9 - (DJ 1 No 249, de 24/12/96) A Lei n 9.099, de 26.09.95, que dispõe sobre os Juízos Especiais Cíveis e Criminais e dá outras providências, não se aplica à Justiça Militar da União. 
sos, é mais uma prova de que a existência da Justiça castrense blinda-se pelo discurso jurídico para a proteção dos princípios normalizadores que a constituem (FONSECA, 2002; FOUCAULT, 1987, 2003).

Os elementos normalizadores da cultura da caserna são tão arraigados ao Sistema Jurídico Nacional que o próprio guardião da Constituição, o Supremo Tribunal Federal (STF), cuja posição na interpretação de temas de direitos fundamentais possui em alguns casos força vinculante, e dessa maneira baliza todo o Poder Judiciário, chega a utilizar em suas decisões argumentos inequívocos da normalização disciplinar:

Está em discussão Supremo Tribunal Federal, a liberação da maconha, que é quase unânime, é a de que quem utiliza a maconha não precisa de tratamento, tanto que se diferencia os defensores da utilização, diferenciam exatamente até de outras drogas, então que não seria alguém que precisaria de um tratamento, ao invés de se submeter aqui à hierarquia ou à disciplina. Inclusive, na Holanda, Portugal, Uruguai, vários Estados Americanos que já liberalizaram a utilização da maconha, do uso da maconha, em vários locais é proibido e, entre um desses locais, exatamente nas Forças Armadas, porque a objetividade jurídica aqui do tipo penal não é somente a questão da utilização, mas, sim, a quebra da bierarquia e disciplina. (Habeas Corpus 115.914 SP. STF primeira turma. Relator Ministro Marco Aurélio, grifo nosso).

Esse encontro da "objetividade jurídica" com a "hierarquia e disciplina", dando provas de como podemos reconhecer a noção do que vem a ser o militarismo jurídico, leva-nos também ao encontro do princípio do escabinato no campo jurídico militar. Tal princípio pode ser compreendido como herança de uma das facetas do direito natural a partir do qual julgadores e jurisdicionados compartilham de crenças e vivências em comum, cujos aspectos morais dessas experiências podem garantir uma melhor compreensão por parte dos julgadores quando forem tomar suas decisões nos casos jurídicos concretos (RIBEIRO, 2013). Disso decorre, na esfera do Direito Penal Militar, tanto para os militares da União, quanto 
para os militares estaduais, que na composição dos Conselhos Permanentes e Especiais de Justiça deva haver a presença tanto de juízes togados como de juízes militares, visto que, se os primeiros dominam o saber jurídico, os últimos possuem um melhor e maior conhecimento da cultura castrense (RIBEIRO, 2013).

Mas eis que aí reside a dificuldade pela presença do militarismo jurídico, pois, se a sociedade possui diversas profissões que não necessitam de um Direito específico para regê-las, no caso da profissão de caráter militar, princípios como o escabinato só reforçam o nosso argumento de como a moral normalizadora subordina as regras normatizadoras do direito. Encontramos um bom exemplo disso no trecho do babeas corpus abaixo destacado, cuja decisão data de 2001, na qual o Procurador da República Mário Pimentel Albuquerque deixa clara a força das normas disciplinares na justiça castrense diante do direito normativo, inclusive dos preceitos constitucionais, ou seja,

A hierarquia e a disciplina constituem, por assim dizer, a própria essência das forças armadas. Se quisermos, portanto, preservar a integridade delas devemos começar pela tarefa de levantar um sólido obstáculo às pretensões do Judiciário, se é que existem, de tentar traduzir em conceitos jurídicos experiências vitais da caserna. Princípios democráticos são muito bons onde há relações sociais de coordenação, mas não em situações específicas, onde a subordinação e a obediência são exigidas daqueles que, por imperativo moral, jurídico ou religioso, as devem aos seus superiores, sejam aqueles, filhos, soldados ou monges. Se o Judiciário, por uma hipersensibilidade na aplicação dos aludidos princípios constitucionais, estimular ou der ensejo a feitos como os da espécie, pronto: os quartéis se superpovoarão de advogados e despachantes; uma continência exigida será tomada como afronta à dignidade do soldado e, como tal, contestada em nome da Constituição; uma mera advertência, por motivo de desalinho ou má conduta, dará lugar a pendengas judiciais intermináveis, e com elas, a inexorável derrocada da hierarquia e da disciplina (ASSIS, 2008, p. 15). 
Em recente movimentação dos atores políticos e dos comandantes das Forças Armadas, foi aprovada a Lei $n^{\circ}$ 13.491, de 13 de outubro de 2017, que ampliou a competência da Justiça Militar da União, colocando-a apta para julgar delitos dolosos contra a vida praticados por militares das Forças Armadas em determinadas circunstâncias. ${ }^{24} \mathrm{O}$ referido ato normativo foi impugnado perante o STF, por meio de uma Ação Direta de Inconstitucionalidade registrada com o n ${ }^{\circ}$ 5901, o Tribunal ainda não se posicionou sobre a matéria que ainda está em vigor.

\section{CONSIDERAÇÕES FINAIS}

A partir do desenvolvimento da pesquisa, analisamos como no sistema militar pátrio há o desenvolvimento da relação entre um ordenamento jurídico militar sustentado por um modelo disciplinar regido por critérios morais não especificamente jurídicos, ou melhor, um militarismo jurídico. No período imperial iniciou-se um processo de codificação de Direitos e Garantias Fundamentais, entretanto, tais preceitos não foram extensivos aos escravos e militares. A Justiça castrense caracterizou-se como um órgão de consolidação do poder da União e, o poder normalizador fazia-se presente em razão da cultura impositiva e arbitrária atribuídas pelos comandantes. O Conselho Supremo Militar e de Justiça, mesmo ciente da utilização de castigos não previstos na legislação, não buscou adotar medidas concretas que sanassem essas ilegalidades.

Proclamada a República, velhas instituições recebem novas denominações, práticas consuetudinárias transmutam-se em leis, comandantes

${ }^{24} \int 2^{\circ}$. Os crimes de que trata este artigo, quando dolosos contra a vida e cometidos por militares das Forças Armadas contra civil, serão da competência da Justiça Militar da União, se praticados no contexto: I - do cumprimento de atribuições que lhes forem estabelecidas pelo Presidente da República ou pelo Ministro de Estado da Defesa; II - de ação que envolva a segurança de instituição militar ou de missão militar, mesmo que não beligerante; ou III - de atividade de natureza militar, de operação de paz, de garantia da lei e da ordem ou de atribuição subsidiária, realizadas em conformidade com o disposto no art. 142 da Constituição Federal e na forma dos seguintes diplomas legais: a) Lei $n^{\circ}$ 7.565, de 19 de dezembro de 1986 - Código Brasileiro de Aeronáutica; b) Lei Complementar n 97, de 9 de junho de 1999; c) Decreto-Lei $n^{\circ}$ 1.002, de 21 de outubro de 1969 - Código de Processo Penal Militar; e d) Lei n 4.737, de 15 de julho de 1965 - Código Eleitoral".

Temáticas, Campinas, 28, (56): 107-136, ago./dez. 2020 
militares são aclamados e eleitos para liderar a nação. O pacto político é rompido e os estados-membros decidiram enfrentar o Poder da União, as forças policiais estaduais são utilizadas como instrumento de resistência e isso atrai a atenção das Forças Armadas.

Em 1934, o pacto federativo é reconstruído e a Justiça Militar é integrada ao Poder Judiciário. Civis foram submetidos aos rígidos regulamentos disciplinares, na condição de assemelhados. Os direitos políticos dos militares foram atribuídos em razão de postos e de algumas graduações na hierarquia militar. A Justiça Militar Estadual, criada por lei, é incorporada à Constituição Nacional em 1946. Uma movimentação dos atores políticos fez com que o novo órgão jurisdicional estadual julgasse oficiais e praças das polícias estaduais nos crimes cometidos em serviços de natureza policial. Até então só podiam ser submetidos ao código militar quando suas corporações eram incorporadas às forças federais. O Supremo Tribunal Federal afirma que a mudança de competência é inaplicável.

O regime militar de 1964 outorgou um novo texto constitucional, e mesmo mantendo partes da Constituição de 1946, ainda assim, possibilitou ao STF modificar seu posicionamento. Novamente as justiças militares passavam a possuir competência para julgar crimes praticados contra civis. O Poder das Forças Armadas sobre os militares estaduais é consolidado. Desde então a organização, instrução, material bélico e regulamentos são controlados pelo Exército, some-se a isso: o ensino, código disciplinar e Código Penal Militar.

A investigação possibilitou reflexões sobre como o ordenamento jurídico castrense é fortemente influenciado por elementos que constituem a cultura militarista e pela força cogente dos pilares das organizações militares, hierarquia e disciplina, na formação dos órgãos jurisdicionais colegiados da Justiça Militar. Em todos os casos, a maioria dos juízes é constituída por militares.

Uma vez investidos na magistratura, os juízes de origem militar devem obediência à normatização jurídica, entretanto, não é incomum encontrar pronunciamentos jurisprudenciais cuja motivação dá-se em razão da tutela dos valores e princípios dos Regulamentos Disciplinares. Trata-se, na verdade, de um profundo equívoco, pois é inapropriado que o 
Direito se aproprie de preceitos próprios da normalização disciplinar e os utilize como razões de decidir. Os elementos de normalização disciplinar não devem proporcionar uma contaminação da argumentação jurídica, mas assim o fazem na esfera castrense, assim como demonstrado no exemplo da proibição do uso da maconha por militares, segundo concepção do STF.

Mais do que isso, nossa argumentação vislumbrou como a justiça castrense, desde sua origem, possibilita que seus órgãos julgadores, até mesmo quando integrantes do Poder Judiciário, continuem a utilizar como ratio cognoscenti valores morais presos a mecanismos disciplinarnormalizadores quando se trata de casos que envolvam direito militar, em razão da utilização de alguns estratagemas presentes na cultura da caserna.

\section{REFERÊNCIAS}

ASSIS, Jorge Cesar de. Curso de direito disciplinar militar: da simples transgressão ao processo administrativo. Curitiba: Jurua, 2008.

BANDEIRA, Esmeraldino. Direito, justiça e processo militar. v. 1. Rio de Janeiro: Francisco Alves, 1919.

BONAVIDES, Paulo. Curso de Direito Constitucional. 15 ed. São Paulo: Malheiros, 2005.

BRASIL. Base da legislação federal do Brasil. Disponível em: http://www4. planalto.gov.br/legislação.

BRASIL. Constituição Política do Império do Brasil de 1824. Disponível em: http://www2.camara.leg.br/legin/fed/consti/1824-1899/constituicao-35041-25-marco-1824-532540publicacaoorigi nal-14770-pl.html

BRASIL. Constituição da República dos Estados Unidos do Brasil de 1891. Disponível em: http://www2.camara.leg.br/legin/fed/ consti/1824-1899/constituicao-35081-24-fevereiro-1891-532699publicacaooriginal-15017-pl.html. 
BRASIL. Constituição da República dos Estados Unidos do Brasil 1934. Disponível em: http://www.planalto.gov.br/ccivil_03/Constituicao/ Constituicao34.htm

BRASIL. Constituição dos Estados Unidos do Brasil1946. Disponível em: http:/ / www.planalto.gov.br/ccivil_03/Constituicao/Constituicao46.htm.

BRASIL. Constituição da República Federativa do Brasil de 1967. Disponível em:http:/ / www.planalto.gov.br/CCivil_03/Constituicao/ Constituicao67.htm

BRASIL. Constituição da República Federativa do Brasil de 1988. Disponível em: http://www.planalto.gov.br/ccivil_03/constituicao/constituicao. htm.

BRASIL. Decreto $n^{\circ}$. 20.348, de 29 de agosto de 1931. Institui conselhos consultivos nos Estados, no Distrito Federal e nos municípios e estabelece normas, sobre a administração local. Disponível em: http:/ /www2.camara.leg.br/legin/ fed/decret/1930-1939/decreto20348-29-agosto-1931-517916-publicacaooriginal-1-pe.html

BRASIL. Supremo Tribunal Federal. Habeas Corpus 115.914 SP Disponível em: http://redir.stf.jus.br/paginadorpub /paginador. jsp?doc'TP=TP\&docID $=14714054$

BRASIL. Relatórios da Repartição dos Negócios da Guerra 1828 a 1940. Disponível em: http://hemerotecadigital.bn.br/acervo-digital/relatorioministerio-guerra/720950

BRASIL. Decreto $n^{\circ} .8 .835$, de 23 de fevereiro de 1942. Aprova o Regulamento Disciplinar do Exército. Disponível em: http://legis.senado.gov.br/legislacao/ListaTextoSigen.action?norma=414772\&i$\mathrm{d}=14452667 \&$ idBinario $=15782072 \&$ mime $=$ application $/ \mathrm{rtf}$

CASTRO, Celso. O espirito militar: Um antropólogo na caserna. Rio de Janeiro: Jorge Zahar Ed., 2004.

CHAVES, Luciano Athayde. O Poder Judiciário brasileiro na colônia e no império: (Des)Centralização, Independência e Autonomia. Revista 
da AJURIS, Porto Alegre, v. 44, n. 143, dez 2017. Disponível em: http://www.ajuris.org.br/OJS2/index.php/REVAJURIS /article/ view/816/Ajuris143DT11.

CORRÊA, Univaldo. A Justiça Militar e a Constituição de 1988: uma visão crítica. Dissertação, Mestrado em Direito. Universidade Federal de Santa Catarina, 1991, p. 517.

COSTA, Fernando Dores. O conselho de guerra como lugar de poder: a delimitação da sua autoridade. Análise social, v. XVIV (191), p. 379-414, 2009. Disponível em: <http://www.scielo.mec.pt/scielo. php?script=sci_arttext\&pid=S0003-25732009000200007>.

COSTA, Fernando Dores. Insubmissão: Aversão ao serviço militar no Portugal do século XVIII. Lisboa: Imprensa de Ciências Sociais, 2010.

LA ORGANIZACIÓN DE LOS ESTADOS AMERICANOS (OEA). Comissão Interamericana de Direitos Humanos. Palamara Iribarne vs. Chile. Disponível em: http://www.corteidh.or.cr /docs/casos/articulos/ seriec_135_esp.pdf

GIL, Antônio Carlos. Métodos e Técnicas de Pesquisa Social. 6a ed. São Paulo: Atlas, 2008.

GOFFMAN, Erving. Manicômios, prisões e conventos. São Paulo: Perspectiva, 2007.

FONSECA, Márcio Alves da. Michel Foucault e o direito. São Paulo: Max Limonade, 2002.

FRANÇA, Fábio Gomes de. Foucault, o direito e a norma: apontamentos para uma reflexão sobre o saber jurídico. Revista Publius, v. 1, n. 1, p. 01 18, jan/jun 2014. Disponível em: <http:/ / www.periodicoseletronicos. ufma.br/index.php/rpublius/article/view/3283>.

FOUCAULT, Michel. Vigiar e punir: história das violências nas prisões. Rio de Janeiro: Vozes, 1987. 
FOUCAULT, Michel. Os anormais. São Paulo: Martins Fontes: 2001.

FOUCAULT, Michel. A verdade e as formas jurídicas. Rio de Janeiro: Ed. Nau, 2003.

FOUCAULT, Michel. Microfísica do poder. Rio de Janeiro: Graal, 2009.

FRANÇA, Fábio Gomes de; DUARTE, Anderson; ALVES, Geni Francinelle. Lei sob a norma: o saber jurídico e os processos normalizadores nas auditorias de Justiça Militar Estadual. Política e Trabalho, Revista de Ciências Sociais, n. 46, p. 71-92, jan./jun. de 2017. Disponível em: <https://periodicos.ufpb.br/index.php/ politicaetrabalho/article/view/32637>.

LOURENÇO, Frederico Ricardo de Ribeiro e. Poder e norma: Michel Foucault e a aplicação do direito. Porto Alegre: Núria Fabris Ed., 2009.

LOUREIRO NETO, José da Silva. Direito Penal Militar. 1. ed. São Paulo: Atlas, 1993.

MENEZES, Delano T. Como pensam os militares: a construção social da subjetividade dos militares. São Paulo: Baraúna, 2015.

MINAYO, Maria Cecilia de Souza (org). Pesquisa Social: teoria, método e criatividade. 28. ed. Rio de Janeiro: Vozes, 2009

PORTUGAL. Regulamento de Infantaria e Artilharia, de 19 de fevereiro de 1763. Disponível em: http://www.governodosoutros.ics.ul.pt/?menu $=$ consulta\&id_partes $=115 \&$ accao $=$ ver\&pagina $=315>$

RIBEIRO, Fernando José Armando. Justiça militar, escabinato e o acesso à justiça justa. Revista do Ministério Público Militar, n. 23, p. 09-31, 2013. Disponível em: <https://revista.mpm.mp.br/ler-artigo/>.

ROCHA, José Manuel de Sacadura. Michel Foucault e o direito. Rio de Janeiro: Forense, 2011.

ROMEIRO. João. Um velho advogado na judicatura militar. Belo Horizonte: Imprensa Oficial, 1962. 
SILVA, Susi Castro et al. (Org.). Direito militar: memória e propostas de trabalho. Fortaleza: Editora Boulesis, 2017.

SOUZA, Adriana Barreto de. A governança da justiça militar entre Lisboa e o Rio de Janeiro (1750-1820). Almanack, Guarulhos, n.10, p.368408, ago. de 2015. Disponível em: <https://www.scielo.br/pdf/ $\mathrm{alm} / \mathrm{n} 10 / \mathrm{pt} \_2236-4633-\mathrm{alm}-10-00368 . p d f>$.

SOUZA, Adriana Barreto de. A Junta do Código Penal Militar de 1802: perspectivas, dilemas e resistências à reforma militar na corte de D. João. Almanack, Guarulhos, n. 18, p. 56-96, abr. 2018. Disponível em: <https://www.scielo.br/scielo.php?pid=S223646332018000100056\&script $=$ sci_arttext $>$.

TURKEL, Gerald. Michel Foucault: law, power, and knowledge. Journal of law and society, v. 17, n. 2, p. 170-193, Summer 1990.

ZAVERUCHA, Jorge. Frágil Democracia e a Militarização da Segurança Pública no Brasil, XII Encontro Anual da ANPOCS, Caxambu, 19-23 outubro 1999, GT no 21 Disponível em: <https://app.uff.br/riuff/ bitstream/1/5847/1/JZaverucha_Fragil.pdf $>$.

ZAVERUCHA, Jorge. FHC, forças armadas e polícia: entre o autoritarismo e a democracia 1999>2002. Rio de Janeiro: Record, 2005.

ZAVERUCHA, Jorge. Relações civil-militares: o legado autoritário da Constituição brasileira de 1988. In: TELES, Edson; SAFATLE, Vladimir (Orgs.). São Paulo: Boitempo, 2010. p. 41-76.

Texto recebido em 22/01/2020 e aprovado em 01/06/2020 